\title{
Use of a proactive herd management system in a dairy farm of northern italy: technical and economic results
}

\author{
Stefania Leonardi, ${ }^{1}$ Gabriele Marchesi, ${ }^{2}$ Francesco Maria Tangorra, ${ }^{1}$ Massimo Lazzari ${ }^{1}$ \\ ${ }^{1}$ Department of Health, Animal Science and Food Safety, Università degli Studi di Milano; \\ ${ }^{2}$ Milkline ${ }^{\circledR}$ S.r.l., Italy
}

\begin{abstract}
Reproductive and economic data were recorded before and one year after the installation of Herd Navigator ${ }^{\mathrm{TM}}$ in a dairy farm with AMS (Automatic Milking System) located in a mountain area of Northern Italy. Number of days open reduced from 166 to 103 days, number of days between the first and second insemination decreased from 45 to 28 days, and days for identifying an abortion were $80 \%$ less, from 31 to 6 days. The preliminary results highlight the usefulness of the proactive herd management system installed for the reproduction management. A basic economic model is proposed to evaluate the potential economic benefits coming from the introduction of this technology. The model considers the benefits deriving from the reduction of reproduction problems and, consequently, of days open. Considering the effects related to the above mentioned aspects in a case study involving 60 dairy cows, a return on investment over 5 years has been calculated.
\end{abstract}

\section{Introduction}

One of the major factors influencing the profitability of a dairy herd is reproductive performance. Following mastitis, failure in detection of oestrus is the second largest cause of economic losses to

dairy farmers (Maatje et al., 1997). Inefficient detection of oestrus has been found to be the leading cause of extended calving intervals (Rounsaville et al., 1979) and the main contributor to the lowering of fertility (Lopez et al., 2004). On the contrary, increasing the detection of oestrus reduces days open and increases profitability with a higher impact at lower oestrus detection rates (Pecsok et al., 1994).

Farris (1954) first described the increased physical activity of dairy

Correspondence: Massimo Lazzari, Department of Health, Animal Science and Food Safety, Università degli Studi di Milano, Via Celoria 10, 20133, Milano, Italy.

E-mail: massimo.lazzari@unimi.it

Key words: days open, oestrus detection, proactive herd management.

(C) Copyright S. Leonardi et al., 2013

Licensee PAGEPress, Italy

Journal of Agricultural Engineering 2013; XLIV(s2):e41

doi:10.4081/jae.2013.s2.e41

This article is distributed under the terms of the Creative Commons Attribution Noncommercial License (by-nc 3.0) which permits any noncommercial use, distribution, and reproduction in any medium, provided the original author(s) and source are credited. cows during oestrus. Later studies have confirmed that the measurement of the increase in the number of steps is a useful tool for the detection of oestrus, especially if associated with a specific algorithm (Moore and Spahr 1991; Lehrer et al 1992; Liu and Spahr 1993; AtTaras and Spahr, 2001; de Mol et al., 2001; Firk et al., 2002; Roelofs et al. 2005).

Many oestrus detection systems are used in attempt to improve conception rates, ranging from the simple visual observation of the animals to more specific systems based on the measurement of the cows' activity through pedometers or collar activity meters (Holman et al., 2011). The effectiveness of pedometer-aided detection of oestrus, when compared with visual observation, is quite variable and ranges from 60 to 100\%, depending on the study (Lehrer et al., 1992). Pennington (1986) reported an efficiency for visual observation of $45 \%$ and for pedometers between $78 \%$ and $96 \%$.

Another system for oestrus detection is the analysis of progesterone in milk (Bulman and Lamming, 1978; 0'Conner, 1993; Royal et al., 2000; Friggens and Chagunda, 2005). In the literature, concentrations less than $3 \mathrm{ng} / \mathrm{ml}$ were considered indicative of an oestrus (Lamming and Bulman 1976). In test carried out on Danish dairy herds, an oestrus breakpoint level of $5 \mathrm{ng} / \mathrm{ml}$ was determined (Friggens et al., 2006).

In 2008 an advanced milk analysis tool (Herd Navigator, DeLaval, Sweden) was developed for heat detection, by measuring progesterone, mastitis detection, by measuring lactate dehydrogenase (LDH), and ketosis detection, by measuring beta-hydroxybutyrate (BHB). This system automatically takes representative milk samples of individual cows from specific milking points during milking and automatically selects, through a specific algorithm called "biomodel", which cows must be monitored and sampled at each milking session, and which parameters should be measured when the animals arrive to the milking parlour (Mazeris, 2010).

Field tests carried out in Denmark between 2008 and 2009 on three farms with more than 150 animals in lactation showed a heat detection rate (HDR) between $95 \%$ and $97 \%$, and a conception rate (CR) ranging from $40 \%$ to $63 \%$, using Herd Navigator (HN). Moreover, $\mathrm{HN}$ reduced the number of days open on an average of 22 days (Blom and Ridder, 2010). Further tests carried out in 2009 on three farms in Denmark and two farms in Holland, with an average of about 180 heads of Holstein Frisian, had showed an HDR between 97\% and 100\% and an improvement of pregnancy rate (PR) from a minimum of $7.7 \%$ to a maximum of $44.4 \%$ (Vreeburg, 2010).

The aim of the study was to evaluate the technical and economic benefits on reproductive management deriving from the introduction of $\mathrm{HN}$ in a dairy cow farm located in a mountain area of northern Italy and characterized by robotic milking. 


\section{Materials and methods}

The study was carried out from September 2011 to September 2012 in a dairy cows farm located in a mountain area of Northern Italy (Trentino-Alto Adige). On average, during the experimental period 60 cows (Holstein Frisian and Brown Swiss) were milked with a Voluntary Milking System (VMS, DeLaval, Sweden) and managed through the integrated herd management software DelPro(DeLaval, Sweden). A HN was installed on September 2011.

- HN is basically composed of:

- a milk sampling station, placed within the VMS, to collect milk samples from individual cows;

- an analysis unit, placed into the milking room, to analyse milk samples for progesterone, LHD, and BHB concentrations.

While cows are being milked, representative milk samples are taken and sent, one-by-one, to the analysis unit. A specific algorithm selects which cow to sample during a certain milking session and which parameters to measure. In particular, the prediction of the reproductive status is driven by the progesterone concentrations in milk. HN takes milk samples for progesterone analysis at varying intervals during the heat cycle, especially on the period up to a new event. After a heat the model asks for samples from day 5 to day 14 to asses if the cow is pregnant or has developed a follicular cyst. Further, the model asks for other samples after day 18 in the heat cycle to find the next heat. In cows that are bred the model follows the development in progesterone: if at day 30 after breeding the progesterone concentration is high, the model assumes that the cow is pregnant and follows the cows for the next 25 days to check for pregnancy.

Basic information describing the farm before the installation of HN such as average number of milking cows over the last 12 months, milk yield per lactation, annual culling rate, etc. were collected through the help of the farmer and the veterinarian of the farm.

During the experimental trial the reproductive status of the cows was monitored using HN. A start time of 20 days before the end of the voluntary waiting period (VWP) was set as start for progesterone measurements and when alarms occurred (follicular or luteal cist, pregnancy attention, abortion, etc.) the cows were examined by the veterinarian at the earliest convenience.

A partial budget analysis was carried out to assess the potential savings on reproductive management of dairy cows, as a consequence of the HN installation. The cash flows changes were identified at the HN introduction, and costs and benefits were evaluated over a period of 8 years from $\mathrm{HN}$ installation.

\section{Results and discussion}

Table 1 summarizes some basic information of the farm involved in the study, before the HN installation. The milk yield level and the difference in milk yield between $3^{\text {rd }}$ and $1^{\text {st }}$ lactation cows are equivalent to the values of the "Po Valley" intensive dairy farms.

The main reproductive data recorded before and after the HN installation are shown in table 2.

The absence of an electronic oestrus identification before the HN installation was the main responsible for the low HDR (45 \%) and PR (18\%), and the high number of days open (166 days) recorded in the farm.

After the HN installation a strong improvement of the reproductive performance was observed. In particular the abortion identification reduced from 31 days to 6 days $(-80 \%)$, the days from $1^{\text {st }}$ and $2^{\text {nd }}$ insemination decreased of about $38 \%$ (from 45 days to 28 days), while the average days open changed on average by 63 days (from 166 days to 103 days). As a consequence, the HDR has more than doubled (from 45 to $96 \%$ ), the CR increased from $40 \%$ to $64 \%$, and the PR grew strongly from $18 \%$ to about $61 \%$.

Main benefits and costs related to the reproductive management, resulting from the HN installation, are summarized in Table 3.

Table 1. Farm overview.

\begin{tabular}{lc} 
Cows in lactation $[\mathrm{n}]$ & 60 \\
Milk yield level [kg/lactation] & 11,000 \\
\hline Difference in milk yield between 3rd and 1st lactation cows [kg] & 1,300 \\
Days per year with reduced attention to heats (harvest, holidays etc.) [gg] & 90 \\
\hline Annual culling rate [\%] & 30 \\
Average salary for own work [€/h] & 20.00 \\
\hline Milk price [€/kg] & 0,40 \\
Average price for heifers - 24 months [€/heifer] & $2,000.00$ \\
\hline Slaughter price per cow culled due to reproduction problems [€/cow] & 500.00 \\
Price per insemination (semen + labour) [€] & 23.00 \\
\hline Cost per pregnancy check [€/day] & 4.00 \\
Cost per days open [€/day] & $€ 2,00$ \\
\hline Voluntary waiting period (VWP) [days] & 60 \\
\hline
\end{tabular}

Table 2. Main reproductive data before and after the HN installation.

\begin{tabular}{lcc}
\hline Reproductive data & Before HN installation & After HN installation \\
No. of pregnancy check per cow per lactation [n] & 3.0 & -0.00 \\
Veterinarian cost [€] & 0.04 & 1.0 \\
\hline Surveillance of pregnancy check [h/check] & 1.0 & 0.04 \\
Time spent to heat detection [h/days] & 85 & 1.0 \\
\hline Avg. of Days In Milk (DIM) at the first insemination [days] & 40 & 65 \\
Days after latest heat for identify luteal cysts (before typically by the time of pregnancy check) [days] & 35.0 & 20 \\
\hline Cystic cows culled [\%] & 31 & 5.0 \\
Days after abortion/lst heat [days] & 45.0 & 6 \\
\hline HDR [\%] & 40.0 & 96.0 \\
CR [\%] & 18.0 & 64.0 \\
\hline PR [\%] & 45 & 61.4 \\
Days from lst to 2nd insemination [days] & 166 & 28 \\
\hline Average days open [days] & 103
\end{tabular}


Table 3. Main benefits and costs related to the reproductive management, resulting from $\mathrm{HN}$ installation

\begin{tabular}{lc} 
Benefits & [euro/year] \\
Increase in average milk yield and less feed due to reduced days open. & $7,560.00$ \\
Reduced labour & $7,300.00$ \\
\hline Reduced veterinarian costs & $4,800.00$ \\
Reduced insemination costs & $2,760.00$ \\
\hline Reduced cull cows & $2,092.50$ \\
Total benefits & $24,512.50$ \\
\hline Costs & \\
\hline Service and sticks $\left(130 € /\right.$ year* ${ }^{*}$ cow) & $7,800.00$ \\
Electrical power & 547.50 \\
\hline Other & 182.50 \\
\hline Total costs & $8,530.00$ \\
\hline
\end{tabular}

Considering an initial investment of $70,000 €$ for the $\mathrm{HN}$, a real interest of $1.5 \%$ (net inflation), an estimated shelf life of 8 years, a recovery value of $10 \%$ compared to the initial value, and an extraordinary maintenance after 4 years as $10 \%$ of the investment value, the following indexes were calculated:

- a five-year Return on Investment (ROI);

- a net annual value of $48,500 €$;

- an Internal Rate of Return (IRR) of 15\%.

Up to the time in which the test was ended, the other HD function associated to mastitis and ketosis detection do not have shown their utility in improving the herd status probably due to the fact that this last was initially of a good level.

\section{Conclusions}

The test has been carried out in a mountain area farm situation in which the herd initial status was characterized by a limited cows number, good milk yield and quite low reproductive indexes. In this specific situation, the HD has shown its capacity to assure a single cow better control that has leaded to an high improvement of the average reproductive indexes. The enhancement of the economic performances related only on this aspect it has been sufficient to guarantee an acceptable ROI value for the economic investment associated to the HD adoption. It can be supposed that these encouraging results would be further improved in the future when the additional management $\mathrm{HN}$ management options (LDH analysis for mastitis detection, Urea and RHR for ketosis detection and feeding improvement) will produce their effect on the herd.

\section{References}

At-Taras, E.E., Spahr, S.L. (2001). Detection and characterization of heat in dairy cattle with an electronic heatmount detector and an electronic activity tag. J. Dairy Sci. 84, 792-798.

Blom J, Ridder C. (2010). Reproductive Management and Performance Can be Improved by Use of DeLaval Herd Navigator®. The First
North American Conference on Precision Dairy Management.

Bulman D.C., Lamming G.E. (1978). Milk progesterone levels in relation to conception, repeat breeding and factors influencing acyclicity in dairy cows. Journal Reproduction Fertility 54, 447-458.

de Mol R.M., Ouweltjes W., Kroeze G.H., Hendriks M.M.W.B. (2001). Detection of estrus and mastitis: field performance of a model. Applied Engineering Agricultural 17, 399-407.

Firk R., Stamer E., Junge W., Krieter J.(2002).Automation of oestrus detection in dairy cows: a review. Livestock Production Science. $75: 219-32$.

Friggens N.C., Chagunda M.G.G. (2005).Prediction of the reproductive status of cattle on the basis of milk progesterone measures: model description. Theriogenology. 64, 155-190.

Holman A., Thompson J., Routly J. E., Cameron J., Jones D. N., GroveWhite D., Smith R. F., Dobson H. (2011). Comparison of oestrus detection methods in dairy cattle. Veterinary Record 2011 169: 47.

Lamming G.E., Bulman D.C. (1976). Use of milk progesterone radioimmunoassay in diagnosis and treatment of subfertility in dairy cows. Br Vet J 132, 507-517.

Lehrer A.R., Lewis G.S., Aizinbud E. (1992). Oestrus detection in cattle: recent developments. Animal Reproduction Science. 28:355-61.

Liu, X., Spahr, S.L., (1993). Automated electronic activity measurement for detection of oestrus in dairy cattle. Journal of Dairy Science 76 (10), 2906-2912.

Lopez H., Satter L.D., Wiltbank M.C. (2004). Relationship between level of milk production and estrous behaviour of lactating dairy cows. Animal Reproduction Science 81:209-223.

Maatje, K., S. H. Loeffler, and B. Engel. 1997. Predicting optimal time of insemination in cows that show visual signs of oestrus by estimating onset of oestrus with pedometers. J. Dairy Sci. 80:1098.

Mazeris F. 2010. DeLaval Herd Navigator ${ }^{\circledR}$ Proactive Herd Management. The First North American Conference on Precision Dairy Management 2010. Toronto, Canada.

Moore A.S., Spahr S.L. (1991). Activity monitoring and an enzyme immunoassay for milk progesterone to aid in the detection of estrus. Journal of Dairy Science 74 (11), 3857-3862.

0'Connor M.L. (1993). Heat detection and timing of insemination for cattle. Penn State University College of Agricultural Sciences. Extension Circular 402, 19

Pecsok, S. R., M. L. McGilliard, and R. L. Nebel. 1994. Conception rates.1. Derivation and estimates for effects of estrus detection on cow profitability. J. Dairy Sci. 77:3008.

Pennington, J. A., J. L. Albright, and C. J. Callahan. 1986. Relationships of sexual activities in oestrous cows to different frequencies of observation and pedometer measurements. J. Dairy Sci. 69:2925.

Roelofs J.B., van Eerdenburg F.J.C.M., Soede N.M., Kemp B. (2005). Pedometer readings for estrous detection and as predictor for time of ovulation in dairy cattle. Theriogenology 64 (8), 1690-1703.

Royal M.D., Darwash A.O., Flint A.P.F., Webb R., Woolliams J.A., Lamming G.E. (2000). Declining fertility in dairy cattle: changes in traditional and endocrine parameters of fertility. Animal Science 70, 487-501.

Rounsaville, T. R., P. A. Oltenacu, R. A. Milligan, and R. H. Foote. 1979. Effects of heat detection, conception rate, and culling policy on reproductive performance in dairy herds. J.Dairy Sci. 62:1435.

Vreeburg N. (2010). Precision Management On Two Dutch Dairy Farms By Use Of Herd Navigator®. The First North American Conference on Precision Dairy Management. 